(c) 2005 Blackwell Publishing, Inc.

\title{
A combined microsatellite multiplexing and boiling DNA extraction method for high throughput parentage analyses in the Pacific Oyster (Crassostrea gigas).
}

\author{
Nicolas Taris ${ }^{1}$, Sophie Baron ${ }^{2}$, Timothy F. Sharbel ${ }^{1}$, Christopher Sauvage ${ }^{1}$ and Pierre \\ Boudry ${ }^{1^{*}}$.
}

\begin{abstract}
1 Institut Français de Recherche pour l'Exploitation de la Mer (IFREMER), Laboratoire de Génétique et Pathologie (LGP), 17390 La Tremblade France
\end{abstract}

2 Laboratoire d'analyses génétiques GENINDEXE, 17000 La Rochelle France

*: Corresponding author : pboudry@ifremer.fr

\begin{abstract}
The analysis of parentage using microsatellite markers is of increasing importance, notably in aquaculture genetic research where communal rearing of mixed families can be used to reduce unwanted environmental variance. We present here an optimization of parental genotype assessment for larvae or adults of the Pacific oyster, Crassostrea gigas, using a multiplex system of three microsatellite loci. In conjunction with a simple DNA extraction protocol, this method enables high throughput analyses of parentage in C. gigas. Using this method, we successfully determined the parentage of $93 \%$ (1224 out of 1318) of the progeny in a factorial cross between 3 females and 10 males. The inability to genotype the remaining $7 \%$ was due to DNA degradation of larvae rather than assignment uncertainty.
\end{abstract}

Keywords: multiplex, larval DNA extraction, high throughput, parental assignment, aquaculture, oysters. 
Microsatellites are ideal markers for genetic mapping studies, analyses of population structure and the assessment of parentage (Jarne \& Lagoda 1996). When analysed in a multiplex fashion, microsatellites provide rapid-turn around time with relatively low material cost for the user (Neff et al. 2000). In aquaculture research, they are especially powerful for parentage determinations in quantitative genetic studies (Mousseau et al., 1998, Vandeputte et al. 2001) and for the assessment of genetic diversity in hatchery populations (e.g. Boudry et al. 2002, Hara et al. 2003). The following technical note describes a high-throughput method composed of a boiling DNA extraction protocol, an optimised triplex microsatellite system, and its application to parentage analyses of Pacific oyster larvae (Crassostrea gigas). The three loci were taken from the literature (CG49 and CG108 from Magoulas et al.1998; L10 from Huvet et al. 2000), and were chosen because they were highly polymorphic $(\approx 40$ alleles per locus, Huvet et al. 2004), and easily scored.

Considering the difficulty of larval DNA extraction due to their small size (from 70 to $300 \mu \mathrm{m})$ and the presence of a hard closed shell, our DNA extraction protocol represents a simple and inexpensive method for large scale studies. It is based on a Chelex-boiling extraction procedure (Estoup et al.1996, Launey \& Hedgecock 2001), but does not require Chelex resin. Individual larvae which had been preserved in $70 \%$ ethanol were collected by pipetting $3 \mu \mathrm{l}$ of ethanol into a $0.2 \mathrm{ml}$ Eppendorf tube, crushed using the point of a clean needle under a dissection microscope, and then dried down in a vacuum centrifuge (Gyrovap, VA Howe) for $15 \mathrm{~min}$ at $35^{\circ} \mathrm{C}$ or at ambient temperature, although this takes more time. Our initial trials using uncrushed larvae produced variable results, and the addition of the crushing step greatly increases the quality of the genotyping results. A $30 \mu \mathrm{l}$ volume of lysate buffer $(670 \mathrm{mM}$ Tris- $\mathrm{HCl}$ $\mathrm{pH} 8.8,166 \mathrm{mM}$ ammonium sulfate, $0.1 \%$ Tween-20) and $5 \mu \mathrm{l}$ of proteinase $\mathrm{K}(1 \mathrm{mg} / \mu \mathrm{l})$ were added to each sample, followed by a short centrifugation step to ensure the larvae were at the bottom of the tube. The tubes were incubated at $55^{\circ} \mathrm{C}$ for $1 \mathrm{~h}$ in a PCR machine (Programmable Thermal Controller- $100^{\mathrm{TM}}$ MJ Research, Inc.), centrifuged briefly and then heated again at $100^{\circ} \mathrm{C}$ for $20 \mathrm{~min}$. The samples were finally transferred from Eppendorf tubes to a 96-well microtiter plate, and stored at $-20^{\circ} \mathrm{C}$ before the PCR procedure. DNA of adult oysters was extracted from a very small gill samples $(\sim 10 \mu \mathrm{g})$ using the same protocol, but using $150 \mu \mathrm{l}$ volume of lysate buffer.

Optimal conditions for a PCR-multiplex reaction may differ markedly from those developed for uniplex reactions (Henegariu et al. 1997, Masi et al. 2003). Consequently, we tested a range of PCR-multiplex conditions by varying primer concentrations, annealing temperatures and reaction volumes (Table 1). Following our initial tests, we adopted the following protocol (reaction volume $15 \mu \mathrm{l})$ : dNTP $(200 \mu \mathrm{M})$, $1 \mathrm{X}$ ThermoPol reaction buffer (New England Biolabs), $\mathrm{MgCl}_{2}(2 \mathrm{mM})$, Taq DNA polymerase (New England Biolabs, $1.5 \mathrm{U} / 15 \mu \mathrm{l})$ and template oyster DNA (100 ng of template DNA for adults and $~ 50 \mathrm{ng}$ for larvae in volume of 1,2 $\mu \mathrm{l}$ ). Initially, annealing temperature was $53^{\circ} \mathrm{C}, 55^{\circ} \mathrm{C}$ and $55^{\circ} \mathrm{C}$ for CG49, CG108 and L10 pairs of primers. In the multiplex PCR reaction, the annealing temperature of $55^{\circ} \mathrm{C}$ gave optimal resolution, although locus L10 could be amplified at $58^{\circ} \mathrm{C}$.

The cycling conditions used for the PCR amplification were as follows: predenaturation $\left(94^{\circ} \mathrm{C}-2\right.$ minutes), followed by 30 cycles of denaturation-annealingextension $\left(94^{\circ} \mathrm{C}-1 \mathrm{~min}\right.$; $\mathrm{T}_{\mathrm{a}}$ [optimal annealing temperature for each pair of primers] $\left.=55^{\circ} \mathrm{C}-1 \mathrm{~min} ; 72^{\circ} \mathrm{C}-1 \mathrm{~min}\right)$, and a final elongation step $\left(72^{\circ} \mathrm{C}-30 \mathrm{~min}\right)$ in order to reduce the double peaks associated with "plus A“ phenomenon (Ziegle et al. 1992). PCR 
products $(1.0 \mu \mathrm{l})$ were finally mixed with $12 \mu \mathrm{L}$ deionized formamide and $0.25 \mu \mathrm{L}$ GeneScan ${ }^{\mathrm{TM}} \mathrm{ROX}^{\mathrm{TM}}$ size standard (Applied Biosystem), denatured for 5 min at $95^{\circ} \mathrm{C}$ and then flash-cooled in a water ice bath. All analyses were performed on a ABI Prism ${ }^{\circledR}$ 3100 automated sequencer (Applied Biosystem) using the POP-4 polymer with the 36 cm capillary.

The extraction-multiplex procedure was performed on 1318 ethanol preserved larvae produced from a cross between 13 known adults (3 females fertilized by 10 males in a factorial design). We chose highly heterozygous parental genotypes from a possible 88 potential adults. To test the resolving power of our three loci in relation to the 13 chosen parental genotypes, we used the FAP (Family Assignment Program) software (J. B. Taggart, University of Stirling; unpublished). This program, based on exclusion principles, revealed that our three multiplexed loci provided $100 \%$ discrimination among the progeny of that cross (assuming no genotyping errors). In practise, we were able to unambiguously determine the parentage in 93\% of the larvae (1224/1318). Dropouts in our genotyping procedure are likely to have been caused by DNA degradation of larvae preserved in ethanol or by human error during the initial larvae sampling, rather than assignment uncertainty.

Additionally, in order to test for the general resolving power of this three locus multiplex system, i.e. without any prior selection of the parental genotypes, we used the simulation program CERVUS (Marshall et al. 1998). This program uses allele frequencies of a population at given locus to estimate its resolving power. The allele frequencies of 88 adult oysters were used to run the simulations according to the following parameters: 10000 replication cycles, $100 \%$ of candidate parents sampled and genotyped. We tested a number of candidate parents ranging from 2 to 88 (fig 1). Assignment to the true parents was successful in $98.5 \%$ of the cases when 2 parents were randomly chosen, and 57,9\% when 88 parents were used. For 13 parents (i.e. our study case), the mean percentage of unambiguous parental assignment was $87 \%$ (not $100 \%)$. This illustrates that, when feasible, the selection of highly heterozygous parents can facilitate parentage analysis (e.g. Boudry et al. 2002).

Despite the inevitable dropout of a small percentage of genotypes due mostly to larval DNA quality factors, our method represents a significant step in the development of parentage studies in C. gigas genetics, and could be extended to the many other microsatellite markers which are now available for this species (Li et al. 2003). 


\section{Acknowledgements}

This work was partially funded by the BRG (Bureau des Ressources Génétiques). We thank Dr. J. Taggart for his comments and his help in using the software "FAP". We would also like to thank the Genindexe lab team for their technical assistance.

\section{References}

Boudry P., Collet B., Cornette F., Hervouet V., Bonhomme F. (2002) High variance in reproductive success of the Pacific oyster (Crassostrea gigas, Thunberg) revealed by microsatellite-based parentage analysis of multifactorial crosses. Aquaculture 204, 283296.

Estoup A., Largiader C.R., Perrot E., Chourrout D. (1996) Rapid one-tube DNA extraction for reliable PCR detection of fish polymorphic markers and transgenes. Molecular Marine Biology and Biotechnology 5, 295-298.

Hara M., Sekino M. (2003) Efficient detection of parentage in a cultured Japanese flounder Paralichthys olivaceus using microsatellite DNA marker. Aquaculture 217, 107-114.

Henegariu O., Heerema N.A., Dlouhy S.R., Vance G.H., Vogt P.H. (1997) Multiplex PCR : critical parameters and step-by-step protocol. Research Reports, Biotechniques 23, 504-511.

Huvet A., Boudry P., Ohresser M., Delsert C., Bonhomme F. (2000) Variable microsatellites in the Pacific oyster Crassostrea gigas and the other cupped oyster species. Animal Genetics 31, 71-72.

Huvet A., Fabioux C., McCombie H., Lapègue S., Boudry P. (2004) Natural hybridization in genetically differentiated populations of Crassostrea gigas and $C$. angulata highlighted by sequence variation in flanking regions of a microsatellite locus. Marine Ecology Progress Series 272, 141-152.

Jarne P., Lagoda P.J.L. (1996) Microsatellites, from molecules to populations and back. Trends in Ecology \& Evolution 11, 424-429.

Launey S., Hedgecock D. (2001) High genetic load in the Pacific oyster Crassostrea gigas. Genetics 159, 255-265.

Li G., Hubert S., Bucklin K., Ribes V., Hedgecock D. (2003) Characterization of 79 microsatellite DNA markers in the Pacific oyster Crassostrea gigas. Molecular Ecology Notes 3, 228-232.

Magoulas A., Gjetvaj B., Terzoglou V., Zouros E. (1998) Three polymorphic microsatellites in the Japanese oyster Crassostrea gigas (Thunberg). Animal Genetics 29, 69-70. 
Marshall T.C., Slate J., Kruuk L., Pemberton J.M. (1998) Statistical confidence for likelihood-based paternity inference in natural populations. Molecular Ecology 7, 639655.

Masi P., Spagnoletti Zeuli P.L., Donini P. (2003) Development and analysis of multiplex microsatellite markers sets in common bean (Phaseolus vulgaris L.). Molecular Breeding 11, 303-313.

Mousseau T.A., Ritland K., Heath D.D. (1998) A novel method for estimating heritability using molecular markers. Heredity 80, 218-224.

Neff B.D., Fu P., Gross M.R. (2000) Microsatellite multiplexing in fish. Transactions of the American Fisheries Society 129, 584-593.

Vandeputte M., Dupont Nivet M., Chatain B., Chevassus B. (2001) Setting up a straintesting design for the seabass, Dicentrarchus labrax : a simulation study. Aquaculture 202, 329-342.

Ziegle J.S., Su Y., Corcoran K.P., Mayrand P.E., Hoff L.B., Mcbridge L.J., Kronich M.N. (1992) Application of automated DNA sizing technology for genotyping microsatellite loci. Genomics 14, 1026-31. 
(A)

\begin{tabular}{ccc}
\hline $\begin{array}{c}\text { Final reaction volume } \\
(\boldsymbol{\mu l})\end{array}$ & \multicolumn{3}{c}{ Annealing temperature $\left({ }^{\circ} \mathbf{C}\right)$} \\
\hline $\mathbf{2 5}$ & $\mathbf{5 5}$ & $\mathbf{5 8}$ \\
$\mathbf{2 0}$ & ++ & + \\
$\mathbf{1 5}$ & ++ & + \\
$\mathbf{1 0}$ & ++ & + \\
\hline
\end{tabular}

(-) no amplification; (+) non-specific amplification; (++) scorable genotype.

(B)

\begin{tabular}{lccc}
\hline & CG108(6-FAM) & L10 (HEX) & CG49 (NED) \\
\hline $0.5 \mu M$ equimolar & 0 & 0 & 0 \\
$0.2 \mu M$ equimolar & + & + & + \\
$0.15 / 0.3 / 0.15 \mu M$ & ++ & ++ & ++ \\
\hline
\end{tabular}

(o) PCR products saturation; (+) scorable but uneven amplification; $(++)$ scorable genotype.

Table 1. Test of variations in multiplex PCR conditions for (A) PCR reaction volume and annealing temperature and (B) primer concentration for markers CG108, L10 and CG49 respectively. 
Taris et al., A combined microsatellite multiplexing and boiling DNA extraction method for oysters.

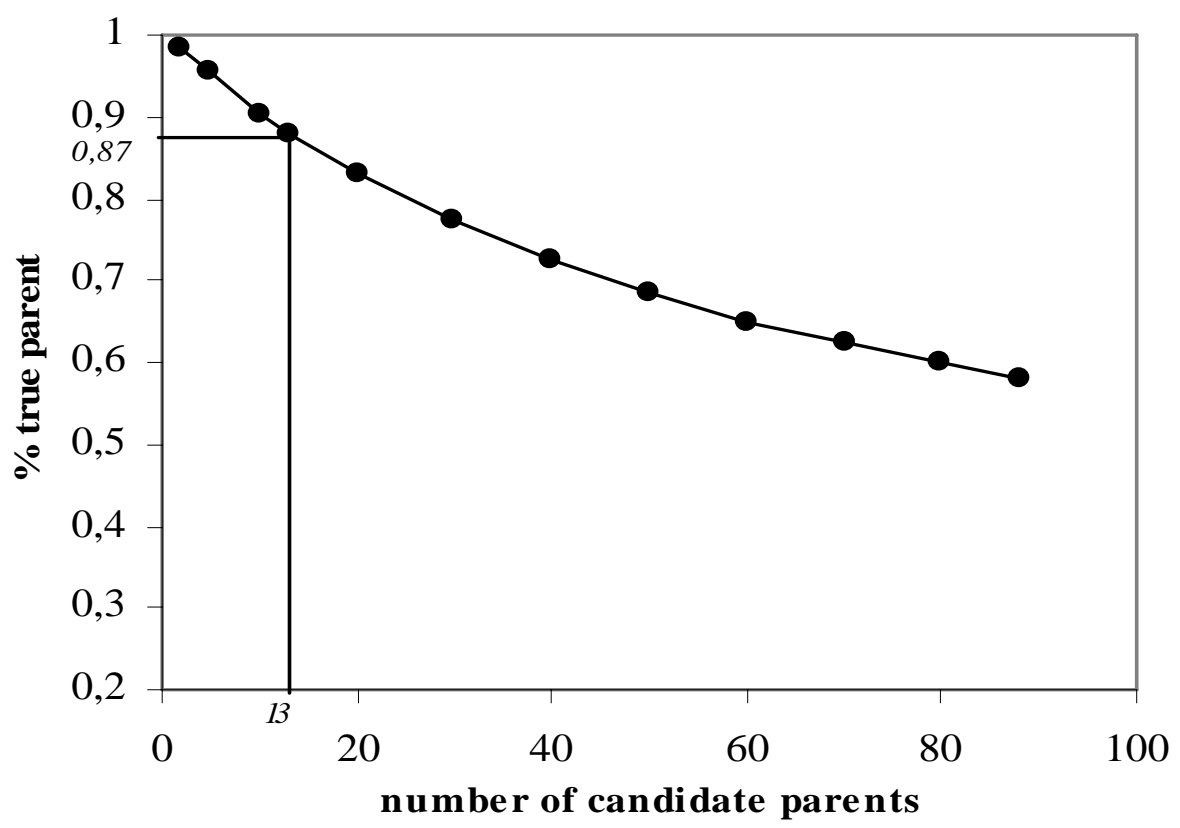

Figure 1. Assignment of offspring in parentage under a number of candidate parents from 2 to 88 . 